\title{
ITIKAD BAIK PADA PENDAFTARAN HAK ATAS TANAH DALAM SISTEM HUKUM PERTANAHAN
}

\author{
Ayu Bimo Setyo Putri \\ Program Magister Kenotariatan Fakultas Hukum Universitas Brawijaya \\ JI. MT. Haryono No 169; Malang; 65145; Indonesia; (0341) 553898 \\ ayubimosp@gmail.com
}

\begin{abstract}
In 1961 the government enacted Government Regulation No. 10 of 1961 on Land Registration, but this regulation can no longer fully achieve maximum results in national development, so it is deemed necessary to make improvements. The purpose of this study is to know and analyze the meaning and benchmarks of good faith in Article 24 Paragraph (2) of Government Regulation No. 24 of 1997 which regulates the procedure of registration of land rights derived from the old right, if evidence is lacking or not at all. This study uses a type of normative juridical research using the approach of legislation and conceptual approach. The meaning of good faith from the experts is not contrary to the existing rules, proper, honest, and does not intend to enrich themselves by harming others. A good measure of faith in the registration of physically controlled land rights uses objective benchmarks in an objective way, if all requirements are met, then it can be said to be in good faith. The procedure provided by this Regulation has provided justice and legal certainty, as the procedure is clear, and if the applicant is proven to do the forbidden, then it may be criminally and civil liable.
\end{abstract}

Keywords: Authorization to Land, Good Faith, Land Law.

\begin{abstract}
Abstrak
Tahun 1961 pemerintah memberlakukan Peraturan Pemerintah Nomor 10 Tahun 1961 tentang Pendaftaran Tanah, tetapi Peraturan ini dirasa tidak dapat lagi sepenuhnya membuat tercapainya hasil yang maksimal pada pembangunan nasional, sehingga dipandang perlu diadakan penyempurnaan. Tujuan penelitian ini adalah untuk mengetahui serta menganalisis makna dan tolok ukur itikad baik dalam Pasal 24 Ayat (2) Peraturan Pemerintah Nomor 24 Tahun 1997 yang mengatur tata cara pendaftaran hak atas tanah yang berasal dari hak lama, jika alat bukti kurang atau tidak ada sama sekali. Penelitian ini menggunakan jenis penelitian yuridis normatif dengan menggunakan pendekatan peraturan perundang-undangan dan pendekatan konseptual. Makna itikad baik dari para ahli yaitu tidak bertentangan dengan peraturan yang ada, pantas, jujur, dan tidak bermaksud untuk memperkaya diri sendiri dengan cara merugikan orang lain. Tolok ukur itikad baik dalam pendaftaran hak atas tanah yang di kuasai secara fisik memakai tolok ukur yang di pandang secara objektif, jika semua persyaratan yang di minta terpenuhi, maka hal tersebut telah dapat di katakan bertitikad baik. Prosedur yang di berikanoleh Peraturan ini telah memberikan keadilan dan kepastian hukum, karena prosedurnya telah jelas, dan apabila pemohon terbukti melakukan hal hal yang di larang maka dapat di pertanggungjawabkan secara pidana maupun perdata.
\end{abstract}

Kata Kunci: Hukum Pertanahan, Hak Atas Tanah,Itikad Baik. 
Salah satu contoh sumber daya alam yang terbatas dan tidak bisa diperbarui adalah Tanah. Ketidakselarasan antara ketersediaan tanah dan kebutuhan manusia yang terus meningka menjadikan munculnya berbagai masalah pertanahan yang ada saat ini. Awalnya ketentuan-ketentuan mengenai pertanahan diatur dalam Undang-Undang Dasar Negara Republik Indonesia Tahun 1945 dalam Pasal 33 Ayat (3) Tentang Hak Menguasai Negara, dimana pasal tersebut mengatur tentang kegunaan bumi, air dan kekayaan alam yang terkandung di dalam kekuasaan negara Republik Indonesia akan dipergunakan untuk sebesar besarnya kemakmuran dan kesejahteraan rakyat.

Pada tahun 1961 diberlakukan Peraturan Pemerintah Nomor 10 Tahun 1961 tentang Pendaftaran Tanah (Lembaran Negara Tahun 1961 Nomor 28), namun keberadaan PP tersebut belum mencapai hasil yang maksimal pada pembangunan nasional, sehingga dipandang perlu diadakan penyempurnaan. Atas dasar tersebut pada tahun 1997, pemerintah mengesahkan Peraturan Pemerintah Nomor 24 Tahun 1997 tentang Pendaftaran Tanah (Lembaran Negara Republik Indonesia Tahun 1997 Nomor 59), yang selanjutnya akan disingkat menjadi Peraturan Pemerintah Nomor 24 Tahun 1997.

Cara penerbitan sertipikat hak-hak atas tanah ini lebih lanjut diatur dalam bagian keempat Peraturan Pemerintah Nomor 24 Tahun 1997. Pembuktian hak baru di jelaskan dalam Pasal 23 sedangkan untuk pembuktian hak lama ada dalam Pasal 24.Pasal 24 Ayat (1) Peraturan Pemerintah Nomor 24 Tahun 1997 ini menjelaskan bahwa untuk hakhak lama yang didaftarkan harus dibuktikan dengan alat bukti yang menunjukkan adanya hak tersebut, alat bukti ini dapat berbentuk bukti tertulis dan keterangan saksi dan atau pernyataan dari yang bersangkutan selaku pemohon dan kadar kebenarannya tersebut akan dinilai secara sistematis oleh panitia ajudikasi atau dapat juga dinilai oleh kepala kantor pertanahan dalam pendaftaran tanah secara sporadik, hingga dinilai cukup layak untuk mendaftarkan hak atas tanah tersebut.
Sedangkan Ayat 2 menjelaskan bila tidak tersedia lagi alat bukti secara lengkap seperti Ayat (1) diatas, maka Ayat 2 ini tetap memungkinkan pendaftaran hak atas tanah tersebut. yaitu dengan penguasaan fisik dengan itikad baik dan tidak di permasalahkan oleh masyarakat. Namun tidak di jelaskan secara tegas apa makna dan tolok ukur itikad baik dalam penguasaan fisik yang di sebut oleh Pasal 24 Ayat (2) Peraturan Pemerintah Nomor 24 Tahun 1997 ini.

Menurut ajaran filsafat Aristoteles dan Thomas Aquinas, pendefinisian merupakan langkah pertama untuk memahami sesuat. Segala sesuatu memiliki esensi ataupun konsep. Esensi dapat menjadi sebuah definisi. Definisi kemudian dapat di gunakan untuk menjelaskan struktur dan karakteristik segala sesuatu yang dalam penelitian ini akan di sebut dengan konsep (Khairandy, 2003).

Permasalahan dalam penelitian ini adalah: belum jelasnya makna itikad baik dalam Pasal 24 Ayat (2) Peraturan Pemerintah Nomor 24 Tahun 1997 Tentang Pendaftaran Tanah, dan tolok ukur konsep itikad baik bagi Badan Pertanahan Nasional dalam pendaftaran hak atas tanah yang diperoleh dari penguasaan fisik. Pada penelitian ini penulis menggunakan jenis penelitian yuridis normatif, dimana penulis menelaah pasal-pasal, asas dan doktrin-doktrin yang memiliki keterkaitan dengan permasalahan yang akan diteliti dalam hal ini pembuktian itikad baik dalam penguasaan tanah secara fisik. Data pada penelitian ini adalah data primer dan sekunder, dimana data penelitian tersebut diambil dengan menggunakan teknik pengambilan data metode studi kepustakaan. Penelitian ini bertujuan untuk memahami dan menganalisa tentang makna itikad baik dalam Pasal 24 Ayat (2) Peraturan Pemerintah Nomor 24 Tahun 1997 Tentang Pendaftaran Tanah; Memahami dan menganalisa tentang tolok ukur itikad baik dalam pendaftaran hak atas tanah yang diperoleh dari penguasaan fisik. 


\section{Perkembangan dan Penafsiran Asas Itikad Baik}

Itikad baik merupakan doktrin atau ajaran yang berasal dari hukum Romawi. Doktrin ini bermula dari sebuah doktrin ex bona fides. Doktrin ini memiliki perjalanan panjang dalam perkembangannya di hukum Romawi (Powers, 1999). Dimulai dari pengakuan terhadap kontrak konsensual informal yang awalnya hanya meliputi kontrak jual beli, sewa-menyewa, persekutuan perdata dan mandat, doktrinitikad baik dalam hukum Romawi berkembang. Doktrin itikad baik berakar pada etika sosial Romawi mengenaikewajiban yang komprehensif akan berlakunya ketaatan dan keimanan baik pada warganegara maupun bukan (Widodo Dwi Putro, 2016).

Pada Hukum Kanonik, kewajiban atas itikad baik menjadi suatu norma moral yang universal dimana secara individual penentunya adalah kewajiban dan kejujuran kepada Tuhan, dimana setiap orang harus memegang teguh atau harus mematuhi janjinya. Itikad baik dan good conscience banyak dihubungkan oleh para sarjana hukum Kanonik. Terdapat makna religious faith ke dalam good faith dalam pengertian hukum (Ridwan Khairandy, 2008).

Hukum Kanonik menggunakan standar moral secara subjektif yang berdasar pada konsep kejujuran individual pada konsep itikad baik.. hal ini jelas berbeda dengan konsep itikad baik dalam hukum Yunani maupun Romawi dimana keduanya memandang itikad baik sebagai suatu universal social force (Powers, 1999).

Di Negeri Belanda, pengaturan itikad baik dalam kontrak terdapat dalam Pasal 1374 Ayat (3) BW (lama) Belanda yang menyatakan bahwa perjanjian harus dilaksanakan dengan itikad baik. P.L. Wery berpendapat bahwa makna pelaksanaan dengan itikad baik (uitvoering tegoeder trouw) dalam Pasal 1374 Ayat (3) di atas masih tetap sama dengan makna bona fides dalam hukum Romawi sebelumnya. Itikad baik memiliki arti dimana kedua pihak harus berlaku satu dengan lainnya tanpa tipu daya dan tanpa tipu muslihat, serta tidak mengganggu pihak lain, tidak hanya memperhatikan kepentingan diri sendiri saja, tetapi juga memperhatikan kepentingan pihak lain (Ridwan Khairandy, 2013).

Itikad baik yang bersifat subjektif ini terletak dalam hukum benda. Itikad baik yang bersifat objektif merupakan konsep umum itikad baik yang mengacu kepada suatu norma perilaku para pihak dalam kontrak bertindak sesuai dengan atau bertentangan dengan itikad baik.Pengaturan itikad baik di Indonesia yang paling umum dapat ditemukan dalam Pasal 1338 Ayat (3) KUHPerdata. Dalam Pasal tersebut diatur bahwa pelaksanaan perjanjian harus berdasarkan itikad baik, namun aturan dalam pasal ini masih terlalu abstrak dikarenakan tidak ada definisi dan tolok ukur itikad baik yang tegas dan jelas dalam KUHPerdata.

Itikad baik merupakan asas penting yang menjadi suatu syarat dalam berbagai sistem perjanjian yang ada. Namun sangat di sayangkan itikad baik ini masih menimbulkan sejumlah persoalan. Persoalan tersebut di antaranya berkaitan dengan keabstrakan makna itikad baik. Sehingga timbul pengertian yang berbeda beda baik dari prespektif waktu, tempat,dan orangnya.

Ridwan Kairandy juga menjelaskan bahwa di negara Eropa seperti Inggris doktrin itikad baik masih controversial dalam pelaksanaannya, hal ini karena pengadilan disana belum dapat mendefinisikan itikad baik secara konkrit, selain itu Amerika Serikat banyak sekali pendapat yang memcoba memberikan pengertian itikad baik (Tatak Eko Yulianto, 2011).Immanuel Kant, seorang ahli filsafat Jerman (1724-1820) berpendapat bahwa apabila ada suatu hal yang absolut baik, adalah keinginan baik (good will) tersebut. Maka dalam hal ini pertanyaannya adalah "Bagaimana dapat diidentifikasi keinginan baik tersebut?" Kant menjelaskan bahwa ada hukum moral yang rasional, yang bisa diidentifikasi berdasarkan akal budi yang rasional pula. 
Baldus mengidenfifikasikan itikad baik dengan equity dan hati nurani, tetapi dia memberikan perhatian khusus kepada suatu persyaratan khusus itikad baik, yaitu bahwa tidak seorangpun boleh memperkaya diri sendiri dengan mengorbankan orang lain. Prinsip ini terlihat seperti prinsip equality yang menurut Aristoteles dan Thomas Aquinas merupakan dasar keadilan kumulatif. Baldus menyebutnya sebagai the rule of rules in the life of consciense(Gordley, 2000). Konsep itikad baik disini mengacu kepada prinsip umum fairness atau equity (epiekeia) dari Aristoteles dan mengakar dalam filsafat hukum alam (Hessenlink, 1999). Baldus tidak mengatakan atas dasar prinsip apa keadilan itu di sandarkan, namun di mengidentifikasikan generik equity dengan prinsip bahwa tidak seorangpun dapat memperkaya diri sendiri dengan mengorbankan orang lain (Gordley, 2000).

Menurut Salim H.S. (2003), terdapat dua jenis asas itikad baik, yang pertama adalahitikad baik nisbi, dimana orang memperhatikan detail dari sikap dan tingkah laku yang nyata dari subyek. Sementara pada itikad baik mutlak, penilaian berada pada akal sehat dan keadilan, selain itu terdapat pula ukuran objektifuntuk menilai keadaan (penilaian tidak memihak) menurut norma-norma yang juga objektif.

\section{Itikad Baik Sebagai Asas dalam Pendaftaran Tanah}

Hukum merupakan suatu alat untuk menyelesaikan masalah yang timbul dalam berbangsa dan bernegara, baik masalah antar individu, masyarakat dengan individu, ataupun individu dengan masyarakat. Soedikno Mertokusumo melalui teori kepastian hukum menjelaskan bahwa ketika suatu peraturan di undangkan secara pasti karena mengatur beberapa hal secara jelas dan logis. Hukum yang logis ditempatkan sebagai norma agar tidak menimbulkan benturan dan kekaburan dalam sistem norma (I Nyoman Satia Negara, 2016). Artinya, sebuah peraturan yang telah di undangkan harus memenuhi unsur jelas dan logis, agar masyarakat dalam melihat hukum yang harus di taati tersebut tidak merasakan suatu ketidakyakinan pada negara ataupun pemerintah yang membuat hukum tersebut.

Pasal 24 Ayat (2) Peraturan Pemerintah Nomor 24 Tahun 1997 menjelaskan bahwa jika tidak tersedia lagi suatu alat bukti secara lengkap, maka pembukuan hak dapat di lakukan berdasarkan kenyataan penguasaan fisik, salah satu syaratnya adalah penguasaan tersebut di kuasai dengan itikad baik. Hal diatas merupakan suatu cerminan bahwa adanya itikad baik yang di gunakan sebagai asas dalam pendaftaran tanah. Sebagai suatu asas, berarti itikad baik ini menjadi suatu syarat yang utama untuk melaksanakan pembukuan hak atau pendaftaran hak atas tanah atau yang sering di sebut masyarakat umum dengan mensertifikatkan fisik tanah.

Penerapan asas itikad baik dapat menjamin perlindungan kepada orang dengan itikad baik untuk memperoleh hak dari orang yang dianggap sebagai pemegang hak secara sah (Titut Rosawati, 2010). Namun menurut Hoge Raad, asas itikad baik ini merupakan doktrin yang berlandaskan kepada kerasionalan dan kepatutan (redelijkheid en billijkheid), sehingga pembuktian itikad baik atas pemilikan hak atas tanah lebih tepat melalui pengadilan. Asas itikad baik dapat dipakai untuk memberi kekuatan pembuktian bagi peta daftar umum yang ada di Kantor Pertanahan (Titut Rosawati, 2010).

Itikad baik yang ada dalam syarat penguasaan fisik yang di jadikan sebagai dasar pendaftaran hak atas tanah ini pun harus jelas dan tidak menimbulkan multi tafsir ataupun kekaburan hukum. Makna itikad baik dalam Pasal 24 Ayat (2) Peraturan PemerintahNomor24 Tahun 1997 ini jika ditelaah dari berbagai pandangan para ahli berarti bermakna bahwa perbuatan untuk menguasai fisik itu dilakukan tanpa tipu daya ataupun tipu 
muslihat yang dilakukan dengan terbuka (diketahui oleh umum/tidak secara sembunyi sembunyi), tanpa pihak lain dan tidak hanya melihat kepentingan pribadi semata, serta dinilai patut dalam norma yang berkembang di masyarakat tersebut.

Kepastian hukum dalam pendaftaran hak atas tanah ini merupakan suatu tujuan yang termuat dalam Pasal 19 UUPA. Karena pendaftaran hak atas tanah berarti juga menerbitkan sertifikat tanah sebagai surat tanda bukti hak yang melekat pada tanah tersebut. Pendaftaran tanah ini merupakan alat bukti yang kuat. Tujuan pendaftaran tanah lebih lanjut di rinci dalam Pasal 3 Peraturan Pemerintah Nomor 24 Tahun 1997 yaitu untuk memberikan kepastian hukum dan perlindungan hukum, menyediakan informasi kepada pihak yang berkepentingan, serta untuk terselenggaranya tertib administrasi pertanahan.

Itikad baik dalam Pasal 24 Ayat (2) Peraturan Pemerintah Nomor 24 Tahun 1997 secara objektif dapat diartikan bahwa pelaksanaan suatu perjanjian wajib memperhatikan norma-norma kepatutan dan kesusilaan sehingga tidak ada dampak kerugian yang dialami oleh salah satu pihak. Sehingga tentu saja pasal tersebut bisa dilaksanakan apabila semua prosedur telah lengkap. Itikad baik dalam Pasal 24 Ayat (2) Peraturan Pemerintah Nomor24 Tahun 1997 berarti belum memenuhi suatu kepastian hukum, di karenakan belum adanya makna yang dijelaskan secara rinci definisi itikad baik yang di maksud dalam pasal ini.

Itikad baik yang ada dalam syarat penguasaan fisik yang di jadikan sebagai dasar pendaftaran hak atas tanah ini pun harus jelas dan tidak menimbulkan multi tafsir ataupun kekaburan hukum. Makna itikad baik dalam Pasal 24 Ayat (2) Peraturan PemerintahNomor 24 Tahun 1997 ini jika di telah dari berbagai pandangan para ahli berarti bermakna bahwa perbuatan untuk menguasai fisik itu dilakukan tanpa tipu daya ataupun tipu muslihat yang di lakukan dengan terbuka (diketahui oleh umum/tidak secara sembunyi-sembunyi), tanpa pihak lain dan tidak hanya melihat kepentingan pribadi semata, serta di nilai patut dalam norma yang berkembang di masyarakat tersebut.

Kepastian hukum dalam pendaftaran hak atas tanah ini merupakan suatu tujuan yang termuat dalam Pasal 19 UUPA. Karena pendaftaran hak atas tanah berarti juga menerbitkan sertifikat tanah sebagai surat tanda bukti hak yang melekat pada tanah tersebut. Pendaftaran tanah ini merupakan alat bukti yang kuat. Tujuan pendaftaran tanah lebih lanjut dirinci dalam Pasal 3 Peraturan PemerintahNomor 24 Tahun 1997 yaitu untuk menjamin kepastian hukum dan memberikan perlindungan hukum dan informasi kepada pihak yang berkepentingan, selain itu juga ditujukan untuk tercapainya tertib administrasi pertanahan.

Guna mewujudkan tujuan pendaftaran tanah ini maka yang bersangkutan di berikan sertifikat hak atas tanah. Dimana dalam suatu sertifikat tanah tercantum data fisik yang melingkupi batas batas tanah tersebut, dan data yuridisnya yaitu setiap pendaftaran, pembebanan, peralihan, dan hapusnya hakatas bidang tanah tersebut. Pendaftaran tanah ini di selenggarakan oleh Badan Pertanahan Nasional. Artinya, semua data data yang terkandung dalam sertifikat hak atas tanah adalah suatu kepastian hukum yang harusnya dapat di pertanggungjawabkan.

Teori kepastian hukum menjadialat analisa dalam dalam penelitian ini dimana teori ini dikemukakan oleh Soedikno Mertokusumo yaitu ketika hukum bisa mewujudkan suatu kepastian hukum berarti hukum tersebut mampu memberikan perlindungan yustiabel terhadap tindakan sewenang-wenang yang berarti individu akan mendapatkan sesuatu yang diharapkan dalam suatu keadaan tertentu. Artinya, dengan memberikan makna itikad baik secara lugas dan jelas dalam Pasal 24 Peraturan PemerintahNomor 24 Tahun 1997 ini akan lebih menjamin adanya suatu kepastian hukum yang menjadi salah satu tujuan hukum. Dengan adanya kepastian hukum maka multi tafsir 
dalam masyarakat akan terminimalisir, dengan begitu akan mengurangi permasalahan terkait dengan pertanahan yang semakin meningkat pada masa ini.

\section{Kesesuaian Tolok Ukur Itikad Baik dalam Pendaftaran Hak Atas Tanah dalam Perspektif Keadilan.}

Hak penguasaan atas tanah merupakan gabungan wewenang, kewajiban dan larangan bagi pemegang haknya untuk berbuat sesuatu untuk tanah yang bersangkutan. Hak penguasaan atas tanah dapat diartikan sebagai lembaga hukum, jika belum dihubungkan dengan tanah tertentu sebagai pemegang haknya (Arba,2015). Namun dalam hal hak penguasaan atas tanah menjadi hubungan hukum yang nyata, jika sudah dihubungkan dengan tanah dan salah satu subjek tertentu sebagai pemegang hak.

Secara umum, penguasaan tanah dapat dibedakan menjadi dua, yaitutanah hak, dan tanah negara. Tanah negara adalah tanah yang langsung dikuasai negara sebagaimana dimaksud dalam UUPA, sedangkan tanah hak adalah tanah yang dipunyai oleh perorangan atau badan hukum dengan suatu hak atas tanah sesuai dengan ketentuan yang berlaku.

Pengertian "penguasaan" dan "menguasai" dapat dipakai dalam berbagai arti fisik, selain secara spesifik dalam arti yuridis, baik perdata maupun publik. Penguasaan secara yuridis dilandasi hak, dilindungi oleh hukum dan memberi kewenangan kepada pemegang hak untuk menguasai secara fisik tanah menjadi haknya. Walaupun ada juga penguasaan secara yuridis yang meskipun kewenangan untuk menguasai tanah secara fisik, pada pelaksanaannya penguasaan fisiknya dilakukan oleh pihak lain. Misalnya apabila tanah yang dimiliki disewakan kepada pihak lain dan penyewa tersebut menguasai tanahnya secara fisik, atau tanah tersebut dikuasai secara fisik oleh pihak lain tanpa hak, dalam hal ini pemilik tanah berdasarkan hak (Syarifah M, 2010).

Penguasaan tanah oleh negara dimaknai sebagai kewenangan negara untuk mengatur peruntukan dan penggunaan dari tanah tersebut, sehingga dapat memberikan kan manfaat sebesar besarnya untuk kesejahteraan rakyat, hal tersebut tentulah seperti amanat yang ada dalam Undang Undang Dasar Tahun 1945. Penguasaan tanah oleh masyarakat hukum adat di maknai sebagai kekuasaan untuk menempati dan menggunakan tanah yang berasal dari hak hak adat. Penguasaan tanah oleh individu atau badan hukum di maknai dengan pemberian hak atau kewenangan untuk memanfaatkan dan menggunakan tanah tersebut untuk kepentingannya.

Hak bangsa memegang hak penguasaan atas tanah yang tertinggi dalam hukum tanah nasional (Arba,2015).Hak bangsa merupakan istilahyang diberikan oleh ilmuwan hukum tanah pada lembaga hukum dan dalam konteks hubungan hukum konkret dengan bumi, air, dan ruang angkasa, termasuk segala kekayaan alam yang terkandung di dalamnya. Hak penguasaan tanah lainnya baik secara langsung maupun tidak langsung bersumber pada hak bangsa, dimana mengandung 2 unsur yaitu kepunyaan dan kewenangan untuk mengatur dan memimpin penguasaan dan penggunaannya secara bersama-sama. Hak bangsa yang dimaksud bukan hak dalam pengertian yuridis. Maka dalam rangka mengatur penguasaan dan memimpin penguasaan tanah bagi hak bangsa dan hak milik perorangan, kewenangan ini ada pada negara.

Kewenangan negara tersebut diwujudkan dengan pendaftaran tanah.Pendaftaran tanah meliputi kegiatan pendaftaran yang terbagi menjadi 2 , yaitu: pengumpulan dan pengolahan data fisik terkait tanah, pembuktian hak dan pembukuannnya, penerbitan sertifikat, penyajian data fisik dan data yuridis, serta penyimpanan daftar umum dan dokumen. Sedangkan pada tahapan pemeliharaan data pendaftaran tanah terdaapt: pendaftaran per- 
alihan dan pembebanan hak, dan pendaftaran perubahan data pendaftaran tanah lainnya.

Keadilan adalah salah satu tujuan hukum yang merupakan salah satu kebutuhan dalam hidup manusia, yang pada umumnya telah diakui di dunia. Aristoteles menyatakan bahwa keadilan akan membagikan kepada setiap orang jatah yang dilihat menurut jasa setiap orang. Artinya, keadilan ini tidak menuntut agar setiap orang mendapat bagian yang sama banyaknya, namun berdasarkan prestasi dan jasa yang telah dilakukan oleh orang tersebut.

Terwujudnya keadilan dalam pendaftaran tanah tidak lepas dari faktor pembentukan dalam substansi aturan pertanahan, dan sinkronisasi peraturan yang ada. Kepastian hukum secara normatif menuntut tersedianya perangkat aturan perundangundangan yang mampu mendukung pelaksanaannya. Sementara secara empiris, keberadaan peraturan-peraturan itu dilaksanakan secara konsisten dankonsekuen oleh sumber daya manusia pendukungnya (Lisa Manalu, 2011).Melihat keadilan tersebut tercapai atau tidak dapat dilihat dari surat pernyataan penguasaan secara fisik yang dibuatkan oleh pemohon pendaftaran tanah yang berisi (Lisa Manalu, 2011):

1. Penguasaan fisik tanah selama 20 tahun. Bahwa fisik tanahnya secara nyata dikuasai dan digunakan sendiri oleh pihakyang mengaku atau secara nyata tidak dikuasai tetapi digunakan pihak lainsecara sewa atau bagi hasil atau dengan bentuk hubungan perdata lainnya.Bahwa tanahnya sedang/tidak dalam keadaan sengketa.

2. Penguasaan tersebut dikuasai dengan itikad baik. Bahwa apabila penandatanganan memalsukan isi surat pernyataan, bersediadituntut di muka hakim secara pidana maupun perdata karena memberikan keterangan palsu.

3. Jika seluruh syarat bagi sebuah surat di bawah tangan telah dipenuhiuntuk dapat dijadikan dasar dalam penerbitan sertifikat hak milik berdasarkan Peraturan Pemerintah Nomor 24 Tahun 1997 ada- lah maka surat di bawah tangantersebut dapat dijadikan sebagai dasar penerbitan sertifikat dan memilikikekuatan pembuktian.

Dengan permohonan yang berisi hal hal diatas, perlindungan hukum dalam mencapai tujuan hukum yaitu adanya suatu keadilan dapat tercapai, sesuai dengan teori Aristoteles yang menyebutkan suatu keadilan dalam jenisnya yaitu keadilan distributif. Peraturan Menteri Agraria Nomor 3 Tahun 1997 merupakan ketentuan pelaksana dari Peraturan Pemerintah Nomor 24 Tahun 1997, karena itu di dalamnya terdapat prosedur yang telah di jelaskan dalam Peraturan Pemerintah 24 Tahun 1997 secara lebih rinci. Jika bukti kepemilikan tidak lengkap maka bukti yang lain dilengkapi dengan pernyataan yang bersangkutan, dan keterangan dari minimal 2 saksi yang bukan keluarga (sampai derajat ke 2 vertikal dan horisontal). Pengumuman data fisik dan data yuridis selama 60 hari di kelurahan. Tujuan pengumuman adalah memberi kesempatan pada pihak pihak yang berkepentingan mengajukan keberatan pada BPN. Proses pendaftaran akan dihentikan bila selama pengumuman ada pihak yang mengajukan keberatan.

Sebagai contoh, Surat Pernyataan Penguasaan Fisik ada yang dibuat atau dinyatakan oleh Kepala Desa atau Kelurahan dan kemudian diketahui penjual yang bersangkutan. Hal seperti ini dianggap banyak kelemahan oleh karena Kepala Desa dianggap rentan terhadap gugatan hukum. Walau pada kenyataannya yang paling tahu dan yang paling bertanggungjawab terhadap kebenaran Pernyataan Penguasaan Fisik Tanah adalah warga pemilik atau penjual tanah tersebut.

Pembuktian hak lama di jelaskan dalam Pasal 24 yang menerangkan dalam ayat pertama yang berbunyi:

"Untuk keperluan pendaftaran hak, hak atas tanah yang berasal dari konversi hak-hak lama dibuktikan dengan alat-alat bukti mengenai adanya hak tersebut berupa bukti-bukti tertulis, keterangan saksi dan atau 
pernyataan yang bersangkutan yang kadar kebenarannya oleh Panitia Ajudikasi dalam pendaftaran tanah secara sistematik atau oleh Kepala Kantor Pertanahan dalam pendaftaran tanah secara sporadik, dianggap cukup untuk mendaftar hak, pemegang hak dan hak-hak pihak lain yang membebaninya."

Pendaftaran tanah dengan pembuktian hak lama yang berasal dari konversi bisa di buktikan dengan alat alat bukti mengenai hak tersebut yang berupa bukti bukti tertulis seperti letter C, Petok D, dan yang lainnya beserta keterangan oleh saksi saksi ataupun pernyataan ataupun penegasan dari pihak yang bersangkutan. Kadar kebenarannya dibuktikan oleh Panitia Ajudikasi jika tanah tersebut di daftarkan secara sistematik atau oleh Kepala Kantor Pertanahan dalam pendaftaran tanah secara sporadik, dan dianggap cukup untuk mendaftarkan hak atas tanah tersebut, termasuk pemegang haknya dan hak lain yang di bebankan pada tanah tersebut.

Dengan demikian, masyarakat yang tidak lagi mempunyai alat bukti kepemilikan hak atas tanah secara lengkap yang di sebutkan dalam penjelasan Pasal 24 Peraturan PemerintahNomor 24 Tahun 1997, tetap bisa mendaftarkan tanahnya menurut pasal di atas. Apabila syarat syarat yang telah di tentukan dalam Pasal 24 Ayat (2) diatas sudah lengkap, maka petugas dari BPN akan melakukan penelitian mengenai hal-hal yang telah disampaikan pemohon tersebut.Sehingga sampai pada kesimpulan mengenai status tanah dan pemegang haknya yang dituangkan dalam keputusan berupa pengakuan hak yang bersangkutan oleh Panitia Ajudikasi dalam pendaftaran tanah secara sistematik dan oleh Kepala Kantor Pertanahan dalam pendaftaran tanah secara sporadik (Khanief, 2012).

Surat Keputusan Pengakuan Hak Atas Tanah ini adalah suatu proses pembuatan sertipikat hak atas tanah. Dimana dengan surat keputusan ini dapat dilakukan dengan melakukan pengumuman selama enam puluh hari. Setelah tidak ada sanggahan dari pihak manapun, maka diterbitkan SK HAT oleh Kepala Kantor Pertanahan dan barulah diterbitkan Sertipikat Tanah, SK Pengakuan dibuat untuk tanah yang memiliki bukti kepemilikan tanah adat, yang berlaku bila sejarah bukti kepemilikan tanah tidak sambung. (Tanpa Penulis, 2016).

Sebuah tolok ukur itikad baik di perlukan dalam penguasaan fisik guna menjamin tercapainya tujuan pendaftaran tanah saat ini yaitu salah satunya adalah tertib administrasi pertanahan, untuk menyediakan data data yang di perlukan untuk kepentingan orang orang yang membutuhkan serta agar para warga sejahtera, dan tidak terjadi sengketa. Hal tersebut tentu saja sesuai dengan citacita negara yang terkandung dalam UndangUndang Dasar Negara Republik Indonesia Tahun 1945 dalam Pasal 33 Ayat (3) yaitu tentang kegunaan bumi, air dan kekayaan alam yang terkandung di dalam kekuasaan negara Republik Indonesia akan dipergunakan untuk sebesar besarnya kemakmuran rakyat.

Mewujudkan dan melindungi tujuan tersebut pastilah memerlukan keadilan dalam hukum yang telah di ciptakan tersebut, agar masyarakat tidak ada yang merasa di rugikan dan merasakan bahwa haknya sebagai warga negara di lindungi oleh hukum yang ada. Itikad baik tersebut tidak hanya mengacu kepada nilai-nilai ada di masyarakat, karena nilai-nilai tersebut merupakan bagian dari masyarakat. Itikad baik inilah yang menggambarkan suatu standar keadilan di masyarakat (Warmelo, 1976).

Itikad baik dalam tahap pelaksanaan kontrak disebut itikad baik ojektif dan standar atau tolak ukur itikad baik pelaksanaan kontrak adalah standar objektif. Hukum kontrak, pengertian bertindak sesuai dengan itikad baik berdasar pada ketaatan akan reasonable commercial standard of fair dealing, yang dapat disebut bertindak sesuai dengan redelijkheid en billijkheid (reasonableness and equity) (Khairandy, 2015). 
Teori kedua yang dapat menganalisis mengenai itikad baik adalah teori keadilan yang dikemukakan oleh Aristoteles yaitu suatu keadilan yang distributif, dimana hukum di buat untuk memberikan sesuatu hal menurut apa yang telah dilakukan oleh orang tersebut. Hal ini berarti bahwa keadilan ini tidak menuntut agar semua orang mendapat bagian yang sama banyaknya, namun berdasarkan apa yang telah dilakukan oleh orang tersebut. Keadilan distributif harus dijamin oleh pemerintah agar setiap warganegara mendapat bagian atas kesejahteraan dan martabat dalam masyarakat secara pantas (Gunawan, 1990).

Tolok ukur yang ada untuk penguasaan fisik yang dijadikan sebagai dasar pendaftaran hak atas tanah ini pun harus adil untuk para pihak yang berkepentingan terhadap bidang tanah yang dikuasai secara fisik yang akan didaftarkan tersebut.Berdasarkan ketentuan pasal ini, apabila persyaratannya tidak dapat dipenuhi walaupun sudah ada yang menguasai tanah tersebut selama 20 tahun berturut-turut maka pemberian hak atas tanah tetap tidak dapat dilaksanakan.

Penilaian kepada alat-alat bukti sebagaimana yang dimaksud dalam Pasal 24, maka akan dilakukan pengumpulan dan penelitian data yuridis mengenai bidang tanah yang bersangkutan oleh panitia Adjudikasi atau Kepala Kantor Pertanahan. Hasil penelitian tersebut dituangkan dalam suatu daftar isian yang ditapkan oleh Menteri. Pendaftaran tanah secara sporadik berdasarkan penelitian data yuridis dilakukan oleh kantor pertanahan menurut ketentuan Pasal 82 Ayat 4 Peraturan Menteri Nomor3 Tahun 1997, dibantu oleh oleh panitia "A", yang dimaksud dalam Keputusan Kepala Badan Pertanahan Nasional Nomor12 Tahun 1992 (Ahmad Akhyar, 2014).

Dilihat dari prosedur prosedur yang telah ada dalam peraturan pemerintah yang dijadikan dasar dalam itikad baik dalam pendaftaran tanah melalui penguasaan fisik ini sudah cukup adil, karena setiap orang tidak diperlakukan sama. Namun diberikan kriteria untuk individu yang bisa mendaftarkan haknya melalui penguasaan fisik ini, yaitu sudah dikuasai selama 20 tahun secara bertutut-turut, dengan kesaksian orang orang yang dapat dipercaya, tidak pernah dipermasalahkan oleh siapapun, dan juga akan dipertanggungjawabkan pernyataan tersebut secara perdata ataupun pidana jika terbukti tidak benar.

\section{Simpulan}

Berdasarkan intrepretasi gramatikal dari beberapa pendapat ahli makna itikad baik adalah suatu niat baik yang berasal dari batin seseorang. Namun para ahli juga merumuskan itikad baik secara nyata yaitu merupakan suatu hal pantas, tidak bertentangan dengan peraturan yang ada, dan tidak bermaksud untuk memperkaya diri sendiri dengan cara merugikan orang lain.

Tolok ukur itikad baik dalam pendaftaran hak atas tanah yang di kuasai secara fisik adalah jika semua prosedur yang telah di tentukan oleh peraturan pemerintah dan peratuan pelaksananya sudah terpenuhi, maka sudah di anggap pemohon tersebut telah mempunyai itikad baik. Karena dalam prosedur tersebut juga mensyaratkan untuk membuat surat pernyataan bahwa jika pemohon siap di tuntut secara pidana ataupun perdata, jika semua persyaratan tersebut terbukti tidak benar.

\section{DAFTAR PUSTAKA}

Akhmad Akhyar., 2014. https://www.slideshare.net/ akhyar25a/bab-i-41481227. 13 Maret 2017.

Arba, 2015. Hukum Agraria Indonesia. Sinar Grafika. Jakarta.

Gordley, James. 2000. Good Faith in Contract in the Medieval Ius Cummune. Cambridge University Press. Cambridge.

Gunawan, A. 1990. Dialekta Hukum dan Moral dalam Pembangunan Masyarakat Indonesia. Kanisus Gunng Mulia. Yogyakarta. 
Hessenlink, Willem. 1999.De Redelijkheid en Billijkheid in het Europese Privaatrecht. Kluwer. Deventer.

Khairandy, Ridwan, 2013. Hukum Kontrak Indonesia dalam Perspektif Perbandingan. Fakultas Hukum Universitas Islam Indonesia Press. Yogyakarta.

Khairandy, Ridwan. 2003. Itikad Baik dalam Kebebasan Berkontrak. Pasca Sarjana Fakultas Hukum Universitas Indonesia. Jakarta.

Khairandy, Ridwan. 2008. Itikad Baik dalam Pelaksanaan Kontrak: Super Eminent Principle yang Memerlukan Pengertian dan Tolok Ukur Objektif. Jurnal Hukum Fakultas Hukum. Nomor 3 Volume 14.

Khairandy, Ridwan. 2015. Kebebasan Berkontrak dan Pacta Sunt Servanda Versus Itikad Baik: Sikap yang Harus Diambil Pengadilan. Fakultas Hukum Universitas Islam Indonesia II Press. Yogyakarta.

Khanief. 2012. Pelaksanaan Pengakuan Hak Atas Tanah Di Kantor Pertanahan Kota Administrasi Jakarta Utara. Penelitian Magister Kenotariatan Fakultas Hukum Universitas Diponegoro Semarang.

M, Syarifah. 2010. Eksistensi Hak Ulayat Atas Tanah Dalam Era Otonomi Daerah Pada Masyarakat Suku Sakai Di Kabupaten Bengkalis Propinsi Riau. Penelitian Magister Kenotariatan Fakultas Hukum Universitas Sumatra Utara Medan.

Manalu Lisa. 2011. Analisis Hukum Terjadinya Pengalihan Hak Atas Tanah Atas Dasar Penguasaan Fisik (Analisis Terhadap Putusan Mahkamah Agung No.475//Pk/ Pdt.2010). Penelitian Magister Kenotariatan Fakultas Hukum Universitas Sumatera Utara Medan.

Negara, I Nyoman Satia. 2016. Kepastian Hukum Pengaturan Pajak Bumi dan Bangunan Terhadap Tanah Adat di Bali. Disertasi Fakultas Hukum Universitas Udayana.

Peraturan Pemerintah Republik Indonesia Nomor 10 Tahun 1961 tentang Pendaftaran Tanah. Jakarta.

Peraturan Pemerintah Republik Indonesia Nomor 24 Tahun 1997 tentang Pendaftaran Tanah. Jakarta.
Powers, Paul J. 1999. Defining the Underfinable: Good Faith and the United Nations Convention on the Contracts for the Internasional Sale of Good.Journal of Law and Commerce. 18 (2): 333-353.

Putro, Widodo Dwi., dkk. 2016. Penjelasan Hukum Pembeli Beritikad Baik Perlindungan Hukum Bagi Pembeli yang Beritikad Baik dalam Sengketa Perdata Berobyek Tanah. http://leip.or.id/wp-content/uploads/ 2016/05/Penjelasan-Hukum-Pembeli-BeritikadBaik-Hukum-Perdata.pdf. 11 Januari 2017.

Rosawati, Titut. 2010. Analisis Pembatasan Sertipikat Hak Milik Atas Tanah Oleh Badan Pertanahan Nasional Sebagai Pelaksanaan Eksekusi Putusan Pengadilan (Studi Kasus Putusan Mahkamah Agung RI Nomor 2096.K/PDT/1987 tanggal 28 Desember 1987 dan Surat Keputusan Kepala Badan Pertanahan Nasional Nomor 4-X.C-2005 tanggal 14 Juli 2005). Penelitian Magister Kenotariatan Fakultas Hukum Universitas Indonesia.

Salim, H. S. 2003. Hukum Kontrak Teori dan Teknik Penyusunan Kontrak. Sinar Grafika.Jakarta.

Tanpa Penulis., 2016. https://omtanah.com/2016/09/ 10/beda-antara-pengakuan-penegasan-konversipemberian-hak-atas-tanah/20 Januari 2017.

Undang-Undang Dasar Republik Indonesia Tahun 1945.

Undang-Undang Republik Indonesia Nomor 5 Tahun 1960 tentang Pokok Agraria. Jakarta.

Warmelo, P. Van. 1976. An Introduction to The Principle of Roman Law. Juta and Co Ltd.Cape Town.

Yulianto, Tatak Eko. 2011. Penyelesaian Sengketa Transaksi Bisnis Internasional E-Commerce Melalui Arbitrase. Skripsi. Fakultas Hukum Universitas Sebelas Maret Surakarta.

\section{How to Cite:}

Putri, Ayu Bimo Setyo. 2017. Itikad Baik Pada Pendaftaran Hak Atas Tanah Dalam Sistem Hukum Pertanahan. Jurnal Cakrawala Hukum. 8 (1): 12-21. 